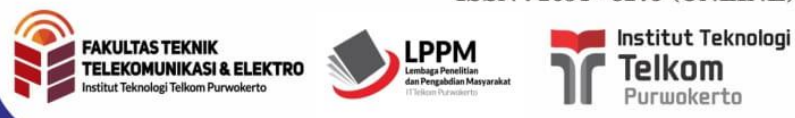

Vol. 3, No. 2, July 2021
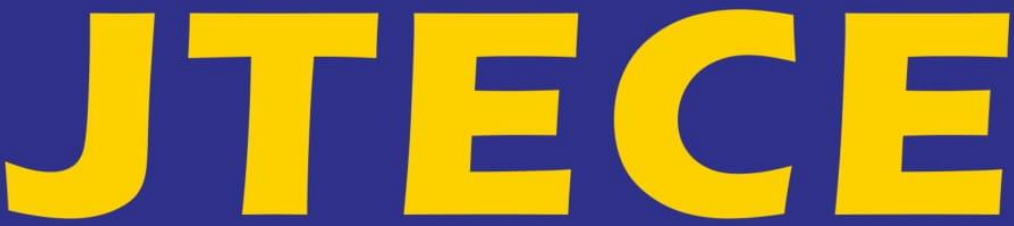

\section{Journal of Telecommunication, Electronics and Control Engineering.}

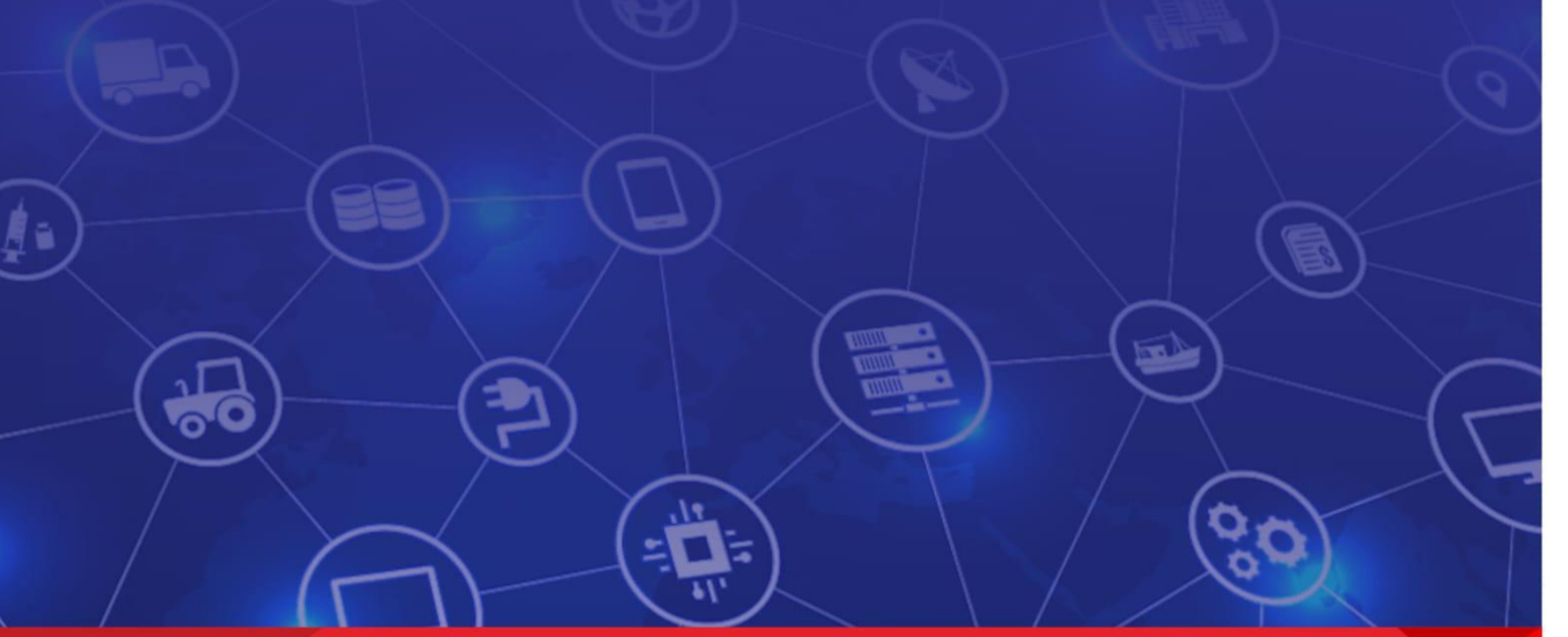

Published by :

Lembaga Penelitian dan Pengabdian Masyarakat (LPPM) Institut Teknologi Telkom Purwokerto, Indonesia
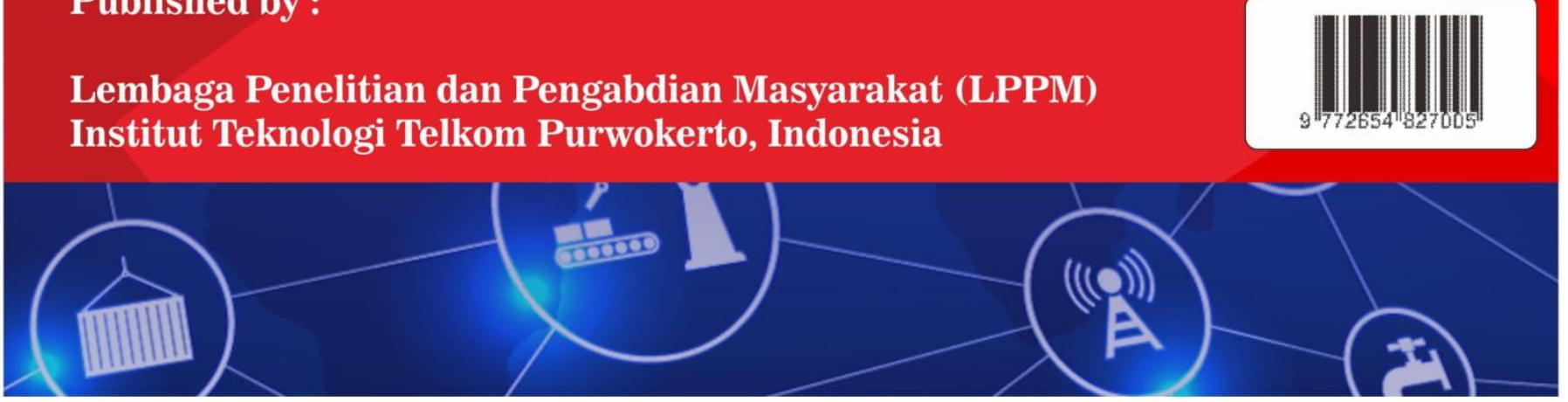